Volume 18, No 4 International Journal of Radiation Research, October 2020

\title{
Possible protective effect of naringin (a citrus bioflavonoid) against kidney injury induced by $\gamma$-irradiation and /or iron overload in male rats
}

\author{
M.M. Ali1 ${ }^{*}$, O.M. Ahmed ${ }^{2}$, A. Sh. Nada', E.S. Abdel-Reheim², \\ N.E. Amin'1 \\ ${ }^{1}$ Drug Radiation Research Department, National center for Radiation Research and Technology (NCRRT) - Atomic \\ Energy Authority, Nasr City, Cairo, Egypt \\ ${ }^{2}$ Physiology Division, Zoology Department, Faculty of Science, Beni-Suef University, Beni-Suef, Egypt
}

- Original article

\author{
*Corresponding authors: \\ Maha M. Ali, Ph.D., \\ E-mail: \\ mahaphysiology@yahoo.com
}

Revised: October 2019

Accepted: December 2019

Int. J. Radiat. Res., October 2020; 18(4): 673-684

DOI: $10.18869 /$ acadpub.ijrr.18.4.673

\begin{abstract}
Background: the supplementation of natural antioxidants such plant flavonoids may counteract the deleterious actions of gamma-irradiation and iron overload. Material and Methods: the protective effect of naringin (NIN) against kidney injury induced by $\gamma$-irradiation (IRR) (6.5 Gy) and/or iron dextran (ID) $(50 \mathrm{mg} / \mathrm{kg}$. b. w) has been studied in rats given $80 \mathrm{mg} / \mathrm{kg} \mathrm{b.w}$ of NIN for 14 days before, and for 7 days after the exposure to $\psi$-irradiation and/ or iron dextran. Results: a significant elevation in serum urea, creatinine, glucose concentrations, and an increase in kidney lipid peroxidation (LPO), ROS and metallothionein (MTs) were observed in rats treated with $\psi$-radiation and/or ID. In addition, a significant decrease in kidney GSH, SOD content, serum total protein, albumin and $A / G$ ratio were also recorded. Tissue organ displayed some changes in trace element concentrations, which may be due to the radiation and/or ID ability to induce oxidative stress. Treatment with NIN revealed a significant modulation in the biochemical tested parameters and a profound improvement in the activity of antioxidant status; thereby appeared to be effective in minimizing the $\gamma$-irradiation and/or ID-induced increase in LPO and ROS as well as changes in essential trace elements in kidney tissue organs. The positive and negative correlation between trace elements and antioxidant markers illuminated antioxidant properties in addition to being an integral part of antioxidant enzymes. Conclusion: NIN has a role in protecting against oxidative stress and kidney injury produced by iron dextran and/or $\gamma$-irradiation.
\end{abstract}

Keywords: y-irradiation, iron overload, oxidative stress, kidney injury, Naringin.

\section{INTRODUCTION}

Most of the toxic effects of ionizing radiation are due to generation of reactive oxygen species (ROS) by radiolysis of water, which triggers the formation of several reactive intermediates and depletion of cellular antioxidants, including glutathione, and enzymatic antioxidants (1). The generation of ROS, resulting in an imbalance in pro-oxidant/antioxidant status in the cells, attacks various components in the cell inducing biochemical changes of diverse cellular macromolecules such as DNA, lipids, and proteins, eventually leading to cell death (2). Efficient defense and repair mechanisms exist in living cells to protect against oxidant species. Superoxide dismutase (SOD) catalyzes the reduction of $\mathrm{O}_{2} \bullet-$ to $\mathrm{H}_{2} \mathrm{O}_{2}$, the majority of which is broken down into oxygen and water by catalase (CAT). In addition to CAT, glutathione peroxidase (GPx) in the presence of adequate amount of reduced glutathione (GSH) can also 


\section{Ali et al. / Radioprotective effect of naringin against kidney injury}

break down $\mathrm{H}_{2} \mathrm{O}_{2}$ (3).

Iron, a trace element, is an essential micronutrient that plays a decisive role in various metabolic processes, including nitrogen fixation, oxygen transport, electron transfer, DNA synthesis and drug metabolism (4). Its ability to donate and accept electron makes it an important molecule of the redox pathways. "Free" iron generates hydroxyl radicals from superoxide and hydrogen peroxide via the Fenton reaction inducing oxidative stress in the cells (5). The hydroxyl free radicals, produced due to participation of iron, are highly reactive. They interact with lipids, proteins and DNA, causing severe damage to these macromolecules and subsequently damage vital tissues and organs (6).

The accumulation of iron is considered detrimental to health as iron overload leads to oxidative stress and triggers several diseases (5). Thus, iron toxicity occurs when there is free iron in the cell, which generally occurs when iron levels exceed the capacity of transferrin to bind the iron (7). The human body does not have any mechanism to remove excess iron, which is stored as a complex with ferritin protein or hemosiderin, which is a degradation product of ferritin (8). This leads to iron-induced oxidative stress that subsequently damages several organs, including the kidneys (9).

Natural antioxidants inhibit the adverse effects of the reactive oxygen species produced in living things and enable them to survive. Depending on this principle, humans started using some plant products to cure from various diseases (10). Naringin (NIN) (4,5,7-trihydroxy flavanone-7-rhamnoglucoside), a major flavanone glycoside in grapefruits and other citrus species, is formed from the flavanone naringenin and the disaccharide neohesperidose (11). Herbal medicinal plants such as Citrus aurantium L., Citrus medica L. and Drynaria quercifolia (L.), are a few reported sources of NIN (12). NIN possesses pharmacological activities such as antioxidant, anti-inflammatory, anti-hyperlipidemic, and antiapoptotic activities (13). NIN and other flavonoids scavenged free radicals due to the presences of phenolic hydroxyl groups (14). Therefore, naringin has been receiving a considerable attention as a nutritional substance to act against oxidative stress and kidney injury induced by iron overload and ionizing radiation. Increased iron content in tissues may increase the risk of cancer and of radiation induced tumor formation. Iron can catalyze the production of oxygen radicals, thus, may render the cell more sensitive to the radicals produced by ionizing radiation. The present work is considered the study that evaluates the protective role of naringin against more than one stress factor (iron overload and ionizing radiation), through its antioxidant, metal chelating and free radical scavenging effect.

\section{MATERIALS AND METHODS}

\section{Experimental animals}

Male Sprague-Dawley rats weighing 120-150 g (age: 4 months) were obtained from Nile Co. for Pharmaceutical and Chemical Industries, Cairo, Egypt. Rats were housed in an air-conditioned atmosphere, at a temperature of $25{ }^{\circ} \mathrm{C}$ with alternatively 12 -h light and dark cycles. Animals were acclimated for 7 days before experimentation. They were kept on a standard diet and water ad libitum. Animals were provided with standard diet pellets (El Nasr Chemical Co., Abou-Zaabal, Cairo, Egypt) contained not less than $20 \%$ protein, $5 \%$ fiber, $3.5 \%$ fat, $6.5 \%$ ash, and a vitamin mixture. The research protocol and experimental procedures were approved by the experimental animal ethics committee of the faculty of science for care and use of animals, Beni Suef University, Egypt (Ethical approval number: BSU/FS/ 2015/21).

\section{Irradiation processing}

Whole body gamma irradiation of animals was carried out at the National Center for Radiation Research and Technology (NCRRT) using the Gamma cell-40® biological irradiator with a $\mathrm{Cs}^{137}$ source (Atomic Energy of Canada Limited; Sheridan Science and Technology Park, Mississauga, Ontario, Canada). The animals were exposed to a single dose of 6.5 Gy gamma ray

Int. J. Radiat. Res., Vol. 18 No. 4, October 2020 
with a dose rate of $0.64 \mathrm{~Gy} / \mathrm{min}$.

\section{Iron overload toxicity}

Iron dextran was purchased from Sigma/ Aldrich, USA. It intraperitoneally was injected to certain groups of animals as $50 \mathrm{mg} / \mathrm{kg} \mathrm{b}$. w. according to Zhao et al. (15).

\section{Treatment}

NIN was purchased from ACROS, New Jersey USA. It was dissolved in distilled water and supplied to certain groups of animals as a daily oral single dose of $80 \mathrm{mg} / \mathrm{kg} \mathrm{b}$. w. according to Pari and Amudha (16) by intra-gastric gavage.

\section{Chemicals}

Thiobarbituric acid (TBA), trichloroacetic acid (TCA), nitroblue tetrazolium, pyrogallol, and formic acid were purchased from Sigma Chemical Co. (St. Louis, MO, USA). All other chemicals and used solvents were of the highest purity and analytical grade.

\section{Study design}

Animals were divided equally into eight groups, each of 8 rats. Group 1 was control group. The rats of group 2 were exposed to 6.5 Gy, a single dose whole body $\gamma$-irradiation and were sacrificed after 7 days post-irradiation. Group 3 received NIN (80 mg/kg b.w.) for 3 weeks by intra-gastric gavage. Group 4 received $80 \mathrm{mg}$ NIN $/ \mathrm{kg}$ b.w. orally for 2 weeks, then exposed to $\gamma$-irradiation 6.5 Gy in the day 14 , followed by treatment with NIN for another week. The rats of group 5 were injected with a dose of ID $50 \mathrm{mg} / \mathrm{kg}$ b.w. by intraperitoneal injection (i.p.) 3 times per week for 2 weeks, followed by a resting period of 7 days. Group 6 received $80 \mathrm{mg}$ NIN / $\mathrm{kg}$ b.w. daily for two weeks and ID $50 \mathrm{mg} / \mathrm{Kg}$ b. w. by i.p. 3 times per week for two weeks, followed by treatment with NIN for another week. The rats of group 7 were intraperitoneally administered with ID (3 times per week) for two weeks, and then exposed to $\gamma$-irradiation 6.5 Gy as a single dose and animals were sacrificed after 7 days. Group 8 received NIN daily for 2 weeks and ID (3 times per week) for two weeks, followed by $\gamma$-irradiation exposure then was administered by NIN for another week.

\section{Sampling}

At the end of the experiment, animals were subjected to diethyl ether anesthesia. Whole blood was collected via heart puncture and left for 1 hour at room temperature and then centrifuged at $3000 \mathrm{rpm}$ for 15 minutes using Hettich Mikro 22R centrifuge (Germany) to separate serum for further analysis. While kidney tissues of each animal were quickly excised, washed with a normal sterile saline, blotted with filter paper, weighed and homogenized in ice-cold istonic saline $(0.9 \%$ $\mathrm{NaCl})$ at a concentration of $10 \%(w / v)$ which was prepared using Glas-Col homogenizer (USA). The homogenates were centrifuged at $3000 \mathrm{~g} \mathrm{rpm}$ for $10 \mathrm{~min}$ at $4^{\circ} \mathrm{C}$ using cooling centrifuge (UNIVERSAL -16 R, Germany) and the supernatant was prepared for analysis.

\section{Biochemical analysis}

Total protein, albumin and globulin were determined using the colorimetric assay kit (BioMed Diagnostic, Germany), Albumin/ globulin $(A / G)$ was calculated. Serum glucose, urea and creatinine were determined using the colorimetric assay kit (BioMed Diagnostic, Germany), The kidney homogenate supernatant was used for determination of the antioxidant parameters such as lipid peroxidation (LPO), reactive oxygen species (ROS), metallothionein (MTs), glutathione (GSH), and superoxide dismutase (SOD) according to Yoshioka et al. (17), Vrablic et al. (18), Onosaka and Cherian (19), Beutler et al. (20) and Minami and Yoshikawa (21) respectively.

\section{Evaluation of trace elements in kidney tissues}

Trace elements were determined in kidney tissue samples after digestion in concentrated pure nitric acid and hydrogen peroxide in 5:1 ratio (22), sample digestion is carried out using Milestone MLS-1200 MEGA, High-Performance Microwave Digestor unit (Italy), the selected elements, $\mathrm{Zn}, \mathrm{Cu}, \mathrm{Mg}, \mathrm{Mn}, \mathrm{Cu}$ and $\mathrm{Fe}$ were estimated using thermo scientific iCE 3000 


\section{Ali et al. / Radioprotective effect of naringin against kidney injury}

Series Atomic Absorption Spectrometry (England), equipped with deuterium background correction. All solutions were prepared with ultra-pure water with a specific resistance $18 \Omega \mathrm{cm}^{-1}$, obtained from ELGA, Ultra-Pure Water Station (England). The biochemical assay was achieved using UNICAM 5625, UV/ VIS Spectrophotometers (England).

\section{Statistical analysis}

Statistical analysis was performed using one-way analysis of variance (ANOVA) followed by post hoc Tukey's HSD (Honestly Significant Difference) test by Graph Pad Prism 5 software packages. Data were presented as mean \pm SE ( $\mathrm{n}=8$ rats/group) with an acceptable level of significance of $p \leq 0.05$. Correlation studies were conducted using Pearson's range coefficient. A p -value $<0.05$ was considered significant in all analyses. The method used for the analysis of the results is that given by Milton et al. (23).

\section{RESULTS}

As shown in table 1, rats exposure to $\gamma$-irradiation resulted in a significant decrease in total protein, albumin and $A / G$ ratio by $-17.1 \%$, $-29.25 \%$ and $-22.14 \%$ respectively compared to the control group. On the other hand, rats injected with ID displayed a significant decrease in albumin and $\mathrm{A} / \mathrm{G}$ ratio by $-14.05 \%$ and $-32.06 \%$ respectively compared to the normal control group. Moreover, the combined group of ID and $\gamma$-irradiation showed a significant decrease in albumin and $A / G$ ratio compared to control and ID groups and a significant decrease in total protein and an increase in globulin compared to irradiated group. ID+ NIN group showed a significant increase in total protein and albumin compared to ID group and a significant increase in globulin and a decrease in A/G ratio compared to the normal control group. Supplementation of rats with NIN alone or with ID before and after whole body $\gamma$-irradiation induced a significant amelioration in the levels of total protein, albumin and globulin and decrease in $A / G$ ratio disturbed by irradiation.
Significant increases in urea and creatinine concentrations were observed, compared to the control, after $\gamma$-irradiation by $22.63 \%$ and 44.44 $\%$ respectively (table 2 ). On the other hand, rats injected with ID displayed a significant increase in creatnine by $40 \%$ compared to the normal group. Moreover, group of ID and $\gamma$-irradiation resulted in a significant increase in creatinine by $46.7 \%$ compared to the control group and a significant increase in urea $35.5 \%$ compared to the normal, IRR and ID groups. Nevertheless, NIN ameliorated the significant increase in creatinine induced by ID; it could improve the increase in creatinine concentration from $40 \%$ to $17.77 \%$ compared to the ID group. Supplementation of rats with NIN pre and post $\gamma$-irradiation ameliorated the observed elevation in urea and creatinine disturbed by $\gamma$-irradiation to be $4.27 \%$ and $4.44 \%$ respectively. Also, the treatment of rats with NIN along with ID pre and post $\gamma$-irradiation induced amelioration in both urea and creatinine level recording $-9.45 \%$ and $20.00 \%$ respectively as compared to the irradiated group.

The results, presented in table 3 , revealed that exposure to $\gamma$-irradiation alone or with iron dextran induced a significant decrease in kidney SOD concentration compared to the normal group. Injection of ID (50 mg/kg) alone or with $\gamma$ -irradiation resulted in a significant decrease in kidney glutathione, while a significant increase in kidney LPO, ROS and MTs was observed in rats intoxicated with ID alone or with $\gamma$-irradiation when compared to the control group. On the other hand, supplementation of NIN with ID, $\gamma$-irradiation or both displayed significant amelioration in kidney GSH, SOD, MTs, LPO and ROS disturbed by $\gamma$-irradiation or iron dextran toxicity.

The results, presented in figure 1 , revealed that whole body $\gamma$ - irradiation resulted in a highly significant increase in glucose level recording percentage changes of $21.28 \%$ compared to the control. Rats injected with ID and exposed to $\gamma$-irradiation revealed a significant increase glucose level by $31.92 \%$ compared to the normal and ID groups respectively. The supplementation of rats with NIN alone or along with ID before and after

Int. J. Radiat. Res., Vol. 18 No. 4, October 2020 
$\gamma$ - irradiation induced a significant modulating effect through amelioration of the increase in glucose disturbed by radiation.

Group of $\gamma$-irradiation induced a significant increase in $\mathrm{Zn} 19.95 \%$ and Ca by $43.76 \%$ and reduction in $\mathrm{Cu}$ with percentage change of $-23.51 \%$ respectively as compared to the control in figure 2. Iron dextran alone induced a significant reduction in $\mathrm{Cu}$ by $-25.32 \%, \mathrm{Mg}$ by $-5.53 \%$ and an increase in $\mathrm{Fe}$ by $65.16 \%$ respectively. While, rats exposed to iron dextran and $\gamma$-irradiation showed a significant decrease in $\mathrm{Cu}$ by $-30.74 \%$ compared to the control and an increase in $\mathrm{Mg}, \mathrm{Ca}, \mathrm{Fe}$ compared to $\gamma$-irradiated group respectively.

Supplementation of irradiated rats with NIN ameliorated the decrease in $\mathrm{Cu}, \mathrm{Mn}$ and $\mathrm{Mg}$ caused by $\gamma$-irradiation recording $-3.61 \%$, $31.61 \%$ and $8.15 \%$ and induced significant increases in $\mathrm{Zn}, \mathrm{Ca}$ and $\mathrm{Fe}$ by $17.51 \%, 52.13 \%$ and $36.63 \%$ respectively compared to the normal control. NIN supplementation to rats intoxicated with ID displayed significant amelioration in $\mathrm{Mg}$ and $\mathrm{Fe}$ concentrations recording $7.96 \%$ and $90.48 \%$ of the controls. On the other hand, NIN and ID with $\gamma$-irradiation induced retention of $\mathrm{Zn}, \mathrm{Cu}, \mathrm{Mn}, \mathrm{Mg}$, $\mathrm{Ca}$ and $\mathrm{Fe}$ by $14.48 \%,-1.03 \%, 44.56 \%, 6.72 \%, 60.26 \%$ and $191.36 \%$ respectively.

Figure 3, showed a positive correlation between GSH and each of $\mathrm{Zn}, \mathrm{Cu}$ and $\mathrm{Mn}$ ( $\mathrm{p}$ value $<0.05$ ). Also, MTs showed a positive correlation with each of $\mathrm{Zn}$ and $\mathrm{Mn}$ ( $\mathrm{p}$ value $<0.05$ ). Additionally, a positive relation between SOD and $\mathrm{Cu}$ was observed.

On the other hand, Figure 4 showed a negative correlation between MDA and each of $\mathrm{Zn}, \mathrm{Cu}, \mathrm{Mg}, \mathrm{Mn}$, and $\mathrm{Ca}(\mathrm{P}$ value $<0.05$ ). In addition, a negative correlation was found between ROS with $\mathrm{Cu}(\mathrm{P}$ value $<0.05)$.

Table 1. Effect of NIN on protein profile in rats exposed to $y$-irradiation and/or intoxicated with ID.

\begin{tabular}{|c|c|c|c|c|}
\hline $\begin{array}{c}\text { Parameters } \\
\text { Groups }\end{array}$ & Total protein (g/dl) & Albumin (g/dl) & Globulin (g/dI) & A/G ratio \\
\hline Control & $7.78 \pm 0.06$ & $4.41 \pm 0.097$ & $3.39 \pm 0.11$ & $1.31 \pm 0.01$ \\
\hline IRR & $6.45 \pm 0.28^{\mathrm{a}}$ & $3.12 \pm 0.054^{\mathrm{a}}$ & $3.32 \pm 0.3$ & $1.02 \pm 0.09$ \\
\% Ch. from Control & -17.09 & -29.25 & -17.09 & -17.09 \\
\hline NIN & $7.79 \pm 0.22$ & $4.24 \pm 0.05$ & $3.55 \pm 0.24$ & $1.24 \pm 0.09$ \\
\% Ch. from Control & 0.13 & -3.85 & 4.72 & -5.34 \\
\hline NIN+IRR & $8.68 \pm 0.2^{\mathrm{ab}}$ & $3.52 \pm 0.037^{\mathrm{ab}}$ & $5.19 \pm 0.22^{\mathrm{ab}}$ & $0.68 \pm 0.03^{\mathrm{ab}}$ \\
\% Ch. from Control & 11.56 & -20.18 & 53.09 & -48.09 \\
\hline ID & $8.02 \pm 0.05$ & $3.79 \pm 0.09^{\mathrm{a}}$ & $4.54 \pm 0.14$ & $0.89 \pm 0.05^{\mathrm{a}}$ \\
\% Ch. From Control & 3.08 & -14.05 & 33.92 & -32.06 \\
\hline NIN+ID & $9.08 \pm 0.16^{\mathrm{ac}}$ & $4.44 \pm 0.067^{\mathrm{c}}$ & $4.51 \pm 0.14^{\mathrm{a}}$ & $0.96 \pm 0.05^{\mathrm{a}}$ \\
\% Ch. from Control & 16.71 & 0.68 & 33.03 & -26.17 \\
\hline ID & $7.668 \pm 0.22^{\mathrm{b}}$ & $2.89 \pm 0.04^{\mathrm{ac}}$ & $4.74 \pm 0.19^{\mathrm{ab}}$ & $0.62 \pm 0.02^{\mathrm{abc}}$ \\
\hline +IRR \% Ch. From Control & -1.54 & -34.24 & 39.82 & -52.67 \\
\hline NIN+ID+IRR & $8.5 \pm 0.16^{\mathrm{b}}$ & $3.51 \pm 0.07^{\mathrm{abd}}$ & $4.85 \pm 0.11^{\mathrm{ab}}$ & $0.71 \pm 0.04^{\mathrm{ab}}$ \\
\% Ch. from Control & 9.25 & -20.23 & 43.06 & -45.80 \\
\hline
\end{tabular}

Values are expressed as mean \pm SE of 8 observations statistically differences were assessed by one way ANOVA followed by Turkey-Kramer multiple comparison test. a, b, c and d indicate significant changes from control, IRR, ID and ID+IRR respectively at $p \leq 0.05$. 
Table 2. Effect of NIN on serum urea and creatinine concentrations in rats exposed to $\mathrm{\gamma}$-irradiation and/or intoxicated with ID.

\begin{tabular}{|c|c|c|}
\hline $\begin{array}{c}\text { Parameters } \\
\text { Groups }\end{array}$ & $\begin{array}{c}\text { Urea } \\
\mathbf{m g} / \mathbf{d l}\end{array}$ & $\begin{array}{c}\text { Creatinine } \\
\mathbf{m g} / \mathbf{d l}\end{array}$ \\
\hline Control & $31.82 \pm 0.55$ & $0.45 \pm 0.01$ \\
\hline IRR & $39.02 \pm 0.46^{\mathrm{a}}$ & $0.65 \pm 0.041^{\mathrm{b}}$ \\
$\%$ Ch. from Control & 22.63 & 44.44 \\
\hline NIN & $30.38 \pm 0.41$ & $0.39 \pm 0.009$ \\
$\%$ Ch. from Control & -4.52 & -13.33 \\
\hline NIN+IRR & $33.18 \pm 1.085^{\mathrm{b}}$ & $0.47 \pm 0.017^{\mathrm{b}}$ \\
$\%$ Ch. from Control & 4.27 & 4.44 \\
\hline ID & $34.5 \pm 0.76$ & $0.63 \pm 0.018^{\mathrm{a}}$ \\
$\%$ Ch. from Control & 8.42 & 40 \\
\hline NIN+ID & $30.52 \pm 0.54$ & $0.53 \pm 0.01^{\mathrm{c}}$ \\
$\%$ Ch. from Control & -4.07 & 17.77 \\
\hline ID+IRR & $43.11 \pm 1.74^{\mathrm{abc}}$ & $0.66 \pm 0.012^{\mathrm{a}}$ \\
$\%$ Ch. from Control & 35.48 & 46.66 \\
\hline NIN+ID+IRR & $28.81 \pm 0.98^{\mathrm{bcd}}$ & $0.54 \pm 0.01^{\mathrm{abd}}$ \\
$\%$ Ch. from Control & -9.45 & 20 \\
\hline
\end{tabular}

Values are expressed as mean \pm SE of 8 observations statistically differences were assessed by one way ANOVA followed by Turkey-Kramer multiple comparison test. a, b, c and $d$ indicate significant changes from control, IRR, ID and ID+IRR respectively at $p \leq 0.05$.

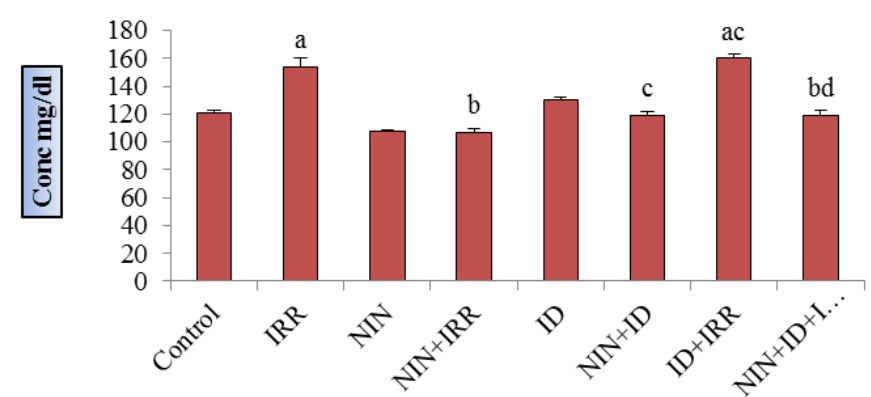

Figure 1. Effect of NIN on glucose concentrations in rats exposed to $\gamma$-irradiation and /or intoxicated with ID.

Values are expressed as mean \pm SE of 8 observations statistically differences were assessed by one way ANOVA followed by Turkey-Kramer multiple comparison test. a, b, $\mathrm{c}$ and $\mathrm{d}$ indicate significant changes from control, IRR, ID and ID+IRR respectively at $p \leq 0.05$

Table 3. Effect of NIN on kidney GSH, SOD, MTs, LPO and ROS concentrations in rats exposed to $\gamma$-irradiation and /or intoxicated with ID.

\begin{tabular}{|c|c|c|c|c|c|}
\hline $\begin{array}{c}\text { Parameters } \\
\text { Groups }\end{array}$ & $\begin{array}{c}\text { GSH } \\
\text { ( } \mu \mathrm{g} / \mathrm{g} \cdot \text { tissue) }\end{array}$ & $\begin{array}{c}\text { SOD } \\
\text { (U/ g. tissue) }\end{array}$ & $\begin{array}{c}\text { MTs } \\
\text { ( } \mu \mathrm{g} / \mathrm{g} . \text { tissue) }\end{array}$ & $\begin{array}{c}\text { LPO } \\
\text { (nmole/g. tissue) }\end{array}$ & $\begin{array}{c}\text { ROS } \\
\left.\text { (U/g.tissue } * 10^{2}\right)\end{array}$ \\
\hline Control & $82.12 \pm 1.32$ & $8.31 \pm 0.05$ & $5.74 \pm 0.29$ & $57.47 \pm 2.52$ & $19.83 \pm 0.82$ \\
\hline $\begin{array}{c}\text { IRR } \\
\% \text { Ch. from Control }\end{array}$ & $\begin{array}{c}74.05 \pm 0.48 \\
-9.82\end{array}$ & $\begin{array}{c}6.73 \pm 0.07^{\mathrm{a}} \\
-19.31\end{array}$ & $\begin{array}{c}6.53 \pm 0.20 \\
13.76\end{array}$ & $\begin{array}{c}60.03 \pm 1.59 \\
4.45\end{array}$ & $\begin{array}{c}21.07 \pm 0.89 \\
6.25\end{array}$ \\
\hline $\begin{array}{c}\text { NIN } \\
\% \text { Ch. from Control }\end{array}$ & $\begin{array}{c}97.24 \pm 1.88^{\mathrm{a}} \\
18.41\end{array}$ & $\begin{array}{c}8.05 \pm 0.06 \\
-3.13\end{array}$ & $\begin{array}{c}7.06 \pm 0.36 \\
22.99\end{array}$ & $\begin{array}{c}60.50 \pm 3.41 \\
5.27\end{array}$ & $\begin{array}{c}14.48 \pm 0.71^{\mathrm{a}} \\
-26.97\end{array}$ \\
\hline $\begin{array}{c}\text { NIN+IRR } \\
\% \text { Ch. from Control }\end{array}$ & $\begin{array}{c}76.64 \pm 0.45 \\
-6.67\end{array}$ & $\begin{array}{c}7.20 \pm 0.08^{\mathrm{ab}} \\
-1.35\end{array}$ & $\begin{array}{c}7.09 \pm 0.35 \\
23.52\end{array}$ & $\begin{array}{c}40.37 \pm 2.62^{\mathrm{ab}} \\
-29.75\end{array}$ & $\begin{array}{c}15.75 \pm 1.04^{\mathrm{ab}} \\
-20.6\end{array}$ \\
\hline $\begin{array}{c}\text { ID } \\
\% \text { Ch. from Control }\end{array}$ & $\begin{array}{c}54.43 \pm 1.7^{a} \\
-33.7\end{array}$ & $\begin{array}{c}7.99 \pm 0.05 \\
-3.85\end{array}$ & $\begin{array}{c}6.54 \pm 0.18 \\
13.94\end{array}$ & $\begin{array}{c}82.73 \pm 4.94^{a} \\
43.96\end{array}$ & $\begin{array}{c}28.06 \pm 0.89^{a} \\
41.5\end{array}$ \\
\hline $\begin{array}{c}\text { NIN+ID } \\
\% \text { Ch. from Control }\end{array}$ & $\begin{array}{c}83.70 \pm 2.04^{c} \\
1.92\end{array}$ & $\begin{array}{c}8.01 \pm 0.02 \\
-3.61\end{array}$ & $\begin{array}{c}7.47 \pm 0.24^{\mathrm{a}} \\
30.14\end{array}$ & $\begin{array}{c}61.27 \pm 2.76^{c} \\
6.61\end{array}$ & $\begin{array}{c}17.47 \pm 0.69^{c} \\
-11.90\end{array}$ \\
\hline $\begin{array}{c}\text { ID+IRR } \\
\% \text { Ch. from Control }\end{array}$ & $\begin{array}{c}71.33 \pm 1.74^{\mathrm{ac}} \\
-13.14\end{array}$ & $\begin{array}{c}7.01 \pm 0.19^{\mathrm{ac}} \\
-15.64\end{array}$ & $\begin{array}{c}8.45 \pm 0.33^{a b c} \\
47.21\end{array}$ & $\begin{array}{c}69.67 \pm 4.25 \\
21.23\end{array}$ & $\begin{array}{c}28.21 \pm 0.96^{\mathrm{ab}} \\
42.25\end{array}$ \\
\hline $\begin{array}{c}\text { NIN+ID+IRR } \\
\% \text { Ch. from Control }\end{array}$ & $\begin{array}{c}95.02 \pm 5.34^{\mathrm{abc}} \\
15.71\end{array}$ & $\begin{array}{c}7.19 \pm 0.08^{a b c} \\
-13.48\end{array}$ & $\begin{array}{c}8.97 \pm 0.47^{a b c} \\
56.27\end{array}$ & $\begin{array}{c}44.80 \pm 2.05^{\mathrm{bcd}} \\
-22.04\end{array}$ & $\begin{array}{c}12.95 \pm 0.55^{\mathrm{abcd}} \\
-34.69\end{array}$ \\
\hline
\end{tabular}

Values are expressed as mean \pm SE of 8 observations, statistically differences were assessed by one way ANOVA followed by Turkey-Kramer multiple comparison test. a, b, c and d indicate significant changes from control, IRR, ID and ID+IRR respectively at $\mathrm{p} \leq 0.05$. 


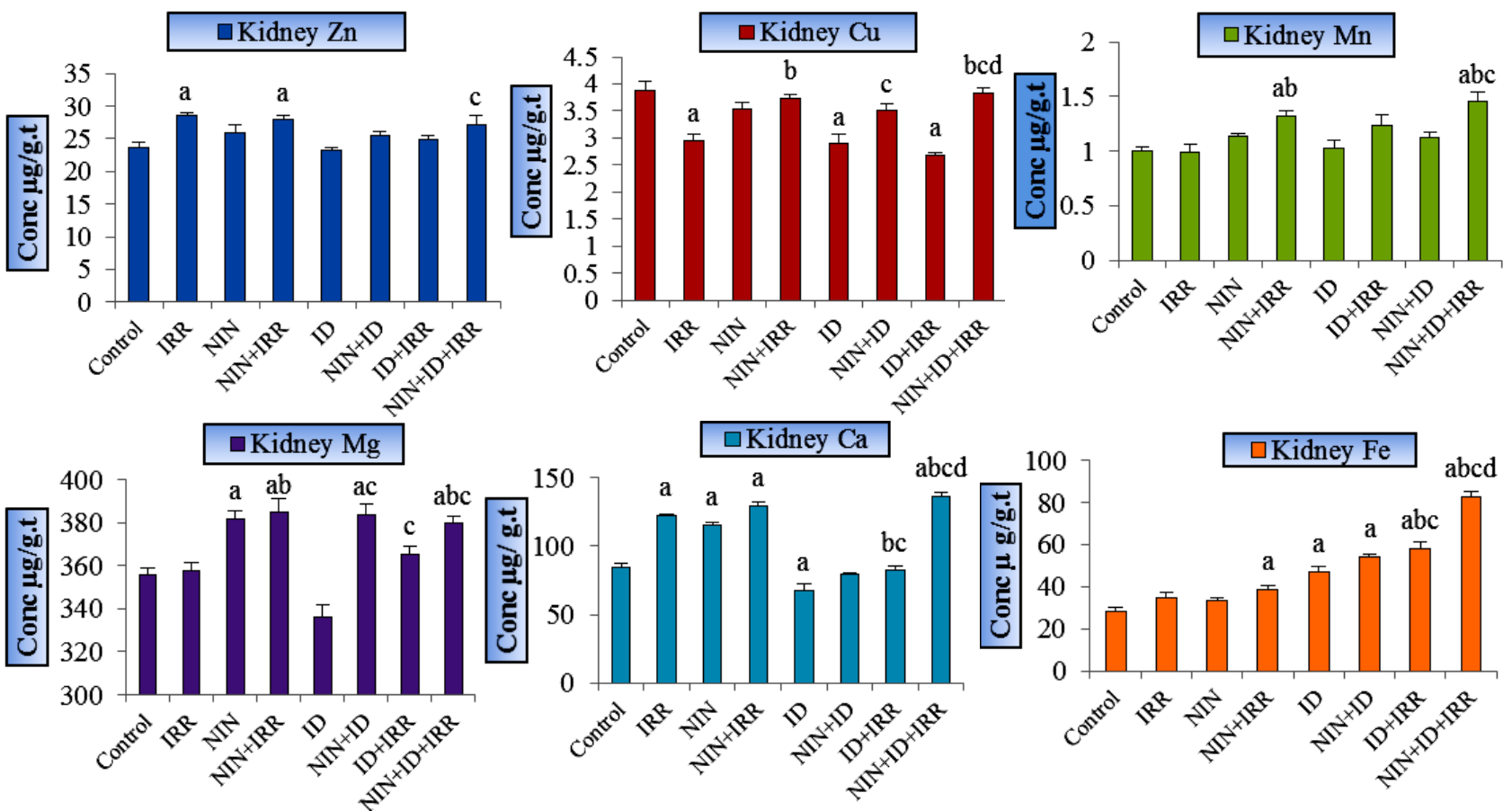

Figure 2. Effect of NIN on renal $\mathrm{Zn}, \mathrm{Cu}, \mathrm{Mg}, \mathrm{Mn}, \mathrm{Ca}$ and Fe concentrations in in rats exposed to $\mathrm{\gamma}$-irradiation and /or intoxicated with ID.

(2) Values are expressed as mean \pm SE of 8 observations statistically differences were assessed by one way ANOVA followed by Turkey-Kramer multiple comparison test. a, b, c and d indicate significant changes from control, IRR, ID and ID+IRR respectively at $p \leq 0.05$.
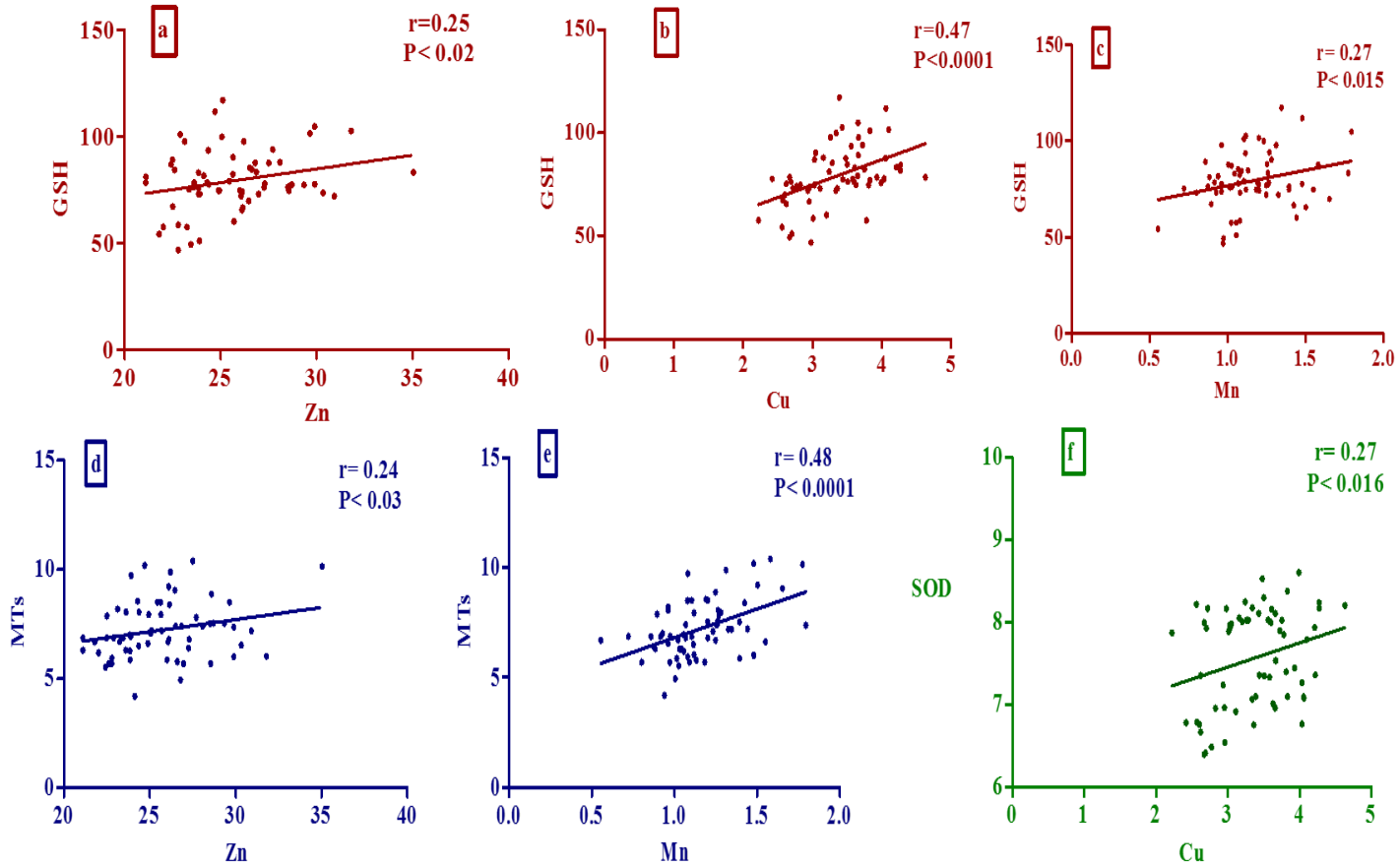

Figure 3. Positive correlation between GSH with $\mathrm{Zn}(\mathrm{a}), \mathrm{Cu}(\mathrm{b}), \mathrm{Mn}(\mathrm{c})$ and MTs with $\mathrm{Zn}(\mathrm{d}), \mathrm{Mn}(\mathrm{e})$ and SOD with $\mathrm{Cu}(\mathrm{f})$ in kidney tissue.

Values are expressed as Pearson ( $r$ ) correlation coefficient, $\mathrm{P}$ value $<0.05$ significant positive correlation. 

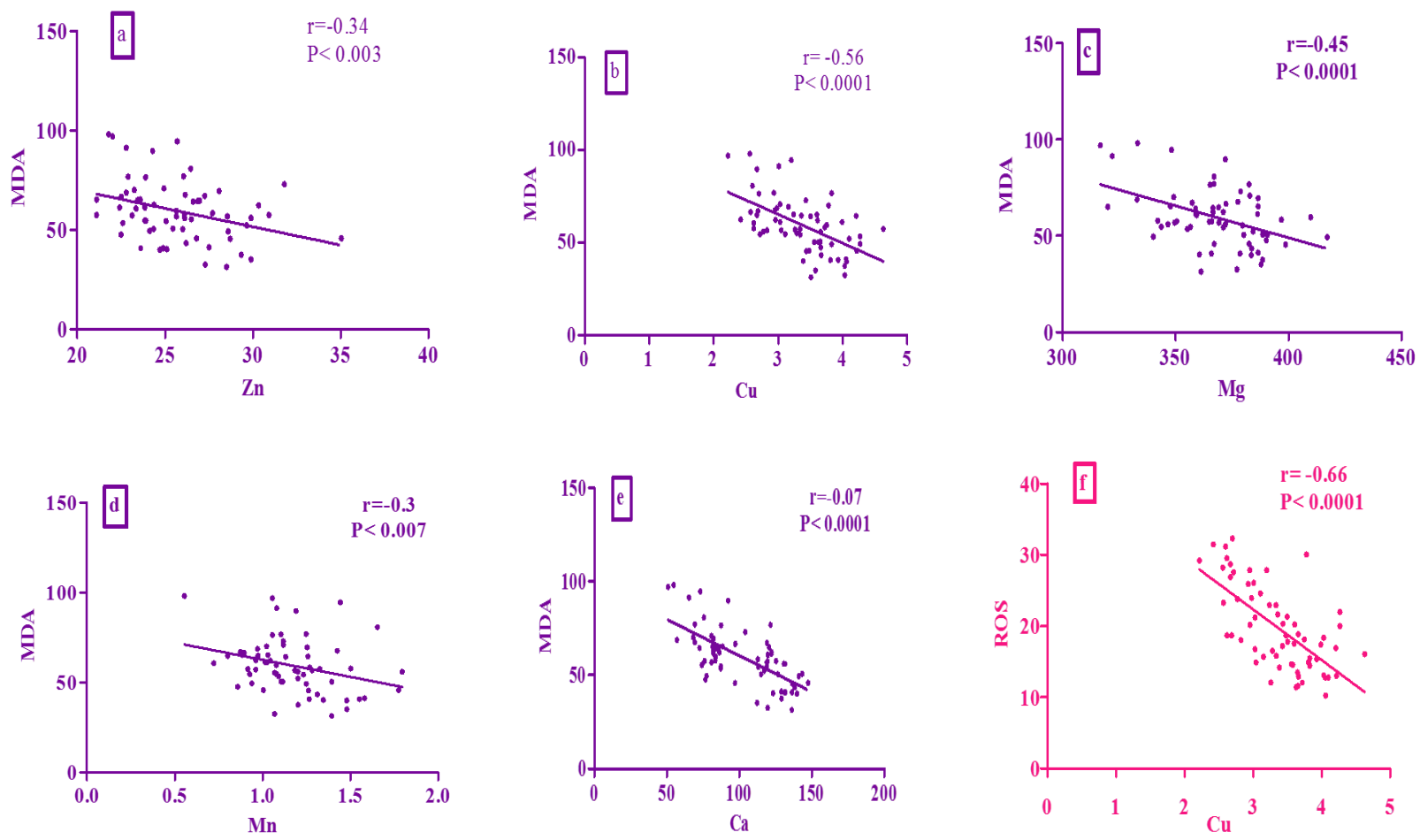

Figure 4. Negative correlation between MDA and each of $\mathrm{Zn}(\mathrm{a}), \mathrm{Cu}(\mathrm{b}), \mathrm{Mg}(\mathrm{c}), \mathrm{Mn}(\mathrm{d})$ and $\mathrm{Ca}(\mathrm{e})$ and between ROS with $\mathrm{Cu}(\mathrm{f})$ in kidney tissue.

(4) Values are expressed as Pearson ( $r$ ) correlation coefficient, $p$ value $<0.05$ significant negative correlation.

\section{DISCUSSION}

The decreases in total protein, albumin and $\mathrm{A} / \mathrm{G}$ ratio level after irradiation were in agreement with Kempner (24) and Kheirallaha and El-Samad (25) who explained that the decrease in protein level due to $\gamma$-irradiation can damage or inactivation of proteins by two different mechanisms. First, it can rupture the covalent bonds in target protein molecules as a direct result of a photon depositing energy into the molecule. Second, it can act indirectly, by linking with a water molecule, producing free radicals and other non-radical reactive oxygen species that are, in turn, responsible for most (99.9\%) of the protein damage. Likewise, iron accumulation disrupts the cell redox balance and generates chronic oxidative stress, which damages DNA, lipids and protein in hepatocytes leading to both necrosis and apoptosis (26). Similarly, the cytotoxic and reactive aldehydic byproducts of LPO induced by iron as MDA, TBARS and 4- hydroxyl -2-non-enal (4-HNE) impair cellular function and protein synthesis (27).

The increased glucose level after irradiation might be related to endocrine glands function abnormalities induced by irradiation that promote the secretion of biologically active peptide which has related to carbohydrate metabolism by increasing gluconeogenesis in liver (28). In the same line, excess iron alters glucose homeostasis and causes a significant increase in glucose level (29) through increasing oxidative/ nitrative stress and reducing antioxidant capacity. Also, the increase in glucose level may be due to the alterations in the hepatic gluconeogenesis enzymes and lipid synthesis as a result of oxidative stress and mitochondrial dysfunction (30).

Significant elevation in urea and creatinine levels was observed after exposure of the animals to $\gamma$-irradiation indicating renal impairment, this may be comparable with those of Talebpour Amiri et al. (31) who attributed these increments to the destruction and 
malfunction of kidney cells due to the action of ROS released post radiation exposure. The exposure to $\gamma$-irradiation induces oxidative deamination of the amino acids, protein catabolism, alterations of the membrane permeability, and damage of the tubular epithelium and other tubule-interstitial components, which deteriorate the kidney function (32).

Likewise, iron dextran induced disturbances in renal functions are similar to those of a previous study (33). This increase could be attributed to the destruction and malfunction of kidney cells due to iron deposition. Under some conditions, the kidney iron deposition may not disturb the renal function (34), but iron overload potentially could enhance the formation of hydroxyl radical, which promotes organ damaging including tubular damage (35).

The data of the current study demonstrated physiological disturbances in the antioxidant status by irradiation and iron overload. The elevated level of MDA in $\gamma$-irradiated rats might be due to the interaction of free radicals with polyunsaturated fatty acids in the phospholipids portion of cellular membranes (36) or due to utilization of the antioxidant system in an attempt to detoxify radiation generated free radicals (37). Also, $\gamma$ radiation caused a depletion of kidney SOD activity and these results were in agreement with those of Ping etal. (38) who showed that irradiation markedly decreased the activity of SOD due to inactivation by ROS.

Similarly, iron is a well-known inducer of ROS and its ability to accelerate lipid peroxidation is well-established; so, iron overload can destruct the balance between pro-oxidants and antioxidants, leading to severe loss of total antioxidant status level (39). Also, Lu et al. (40) explained that cells could actively produce ROS through a family of tightly regulated NADPH- oxidases (NOXs), homologues of phagocyte oxidase. Antioxidant enzymes such as CAT and GPx operate in performance with non-enzymatic molecules such as GSH to antagonize the ROS actions and to avoid oxidative damage (41). The SOD dismutates $\mathrm{O}_{2}$ which produced by fenton reaction of iron overload into less harmful product hydrogen peroxide and acts as a first line of defense against oxidative stress (42).

Regarding the concentration levels of different metals in kidney tissues, it was observed that $\gamma$-irradiation induced increases in $\mathrm{Zn}$ and $\mathrm{Ca}$ levels and a significant reduction of $\mathrm{Cu}$ in kidney tissues. The increase of $\mathrm{Zn}$ may be due to its accumulation from the damaged lymphoid organs, bone marrow and spermatogonia for stimulating the induction of metallothioneins (43). So, the antioxidant role of $\mathrm{Zn}$ could be related to its ability to induce metallothioneins (MTs), this can reduce the toxic effects of several types of free radical including superoxide, hydroxyl and peroxyl radicals induced by ionizing radiation (44).

In addition, during oxidative stress, the inadequate generation of ATP can cause malfunctioning of calcium ATPase pumps and an increase in intracellular calcium (45). Irradiation causes ischemic cell injury associated with rushed influx of calcium from extracellular into intracellular compartment and such ischemia results from the damaged small blood vessels (46). Contrariwise, the observed declines in $\mathrm{Cu}$ level could be attributed to the excess of its utilization via coperoenzymes, which are able to reduce oxygen to water or to hydrogen peroxide (47) or may be due to de novo synthesis of $\mathrm{Cu}$-SODs and CAT which prevents the formation of $\mathrm{O}_{2}$ and hydroxyl radical associated with irradiation (48).

In the present study, iron dextran showed a significant increase in Fe level and decrease in $\mathrm{Cu}$ and $\mathrm{Ca}$ in kidney tissues. Increased iron level may be due to oxidative stress inducing proteolytic modification of ferritin (49) and transferrin. Free iron facilitates the decomposition of lipid hydroperoxides resulting in a lipid peroxidation and induces the generation of $\cdot \mathrm{OH}$ radicals and also accelerates the non-enzymatic oxidation of glutathione to form $\mathrm{O}_{2}$ radicals ${ }^{(50)}$. The reduction in $\mathrm{Cu}$ concentration could be attributed to that excess iron can antagonize copper metabolism (51). The mechanism by which iron overload perturbs copper homeostasis occurs is unknown. One seeming likely possibility is that high iron levels in the intestinal lumen impair copper absorption 


\section{Ali et al. / Radioprotective effect of naringin against kidney injury}

(52).

Positive and negative correlations were observed in kidney tissue between trace elements and antioxidants status markers. These results were possible to explain that these elements ( $\mathrm{Se}, \mathrm{Zn}, \mathrm{Cu}, \mathrm{Mn}, \mathrm{Ca}$ and $\mathrm{Mg}$ ) possess antioxidant properties in addition to being an integral part of antioxidant enzymes such as GPx, SOD and MTs. Thus, the increased generation of ROS led to increased lipid peroxidation and MDA level; therefore decreased levels of these elements are a result of their use in protecting cells against the harmful effects caused by ROS (53).

The negative correlation between MDA and $\mathrm{Zn}$ in the present study was in agreement with Salem et al. (54); this correlation was supported by the presence of $\mathrm{Zn}$ in many antioxidant enzymes such as CAT, GPx, and SOD. Hence, Zn deficiency might lead to oxidative stress. Furthermore, a negative correlation with $\mathrm{Cu}$ was attributed to the accumulation of lipid peroxidation, which decreased hepatic synthesis of ceruloplasmin (the major $\mathrm{Cu}$ carrying protein in blood) and resulted in a low concentration of $\mathrm{Cu}$ in liver (55).

The results demonstrated that NIN administration ameliorates the observed elevation in urea, creatinine and glucose levels and the decrease in $T$. protein, albumin, $A / G$ ratio induced by $\gamma$-irradiation and iron dextran. NIN stabilizes the hepatic cellular membrane and protects the hepatocytes, which may decrease the leakage of the enzymes into the blood stream. This can be attributed to the antioxidant property of NIN (56), the ability to scavenge free radicals and the ability to inhibit lipid peroxidation (57). Also, the protective effect of NIN in hyperglycaemic conditions may be associated with an intensification of glucose uptake by peripheral tissues, a reduction in plasma glucose concentration with stimulation of insulin secretion (58).

NIN boosted the antioxidant system in the present study. The antioxidant effects of NIN have been shown to be similar to those of GSH. Furthermore, it is reported to inhibit the hydrogen peroxide-induced lipid peroxidation
(59). NIN has been demonstrated to play an important role in regulating anti-oxidative capacity by increasing SOD and catalase activities and by up-regulating the gene expression of SOD, catalase, and glutathione peroxidase (56).

The present study showed that NIN induced more retention of iron, copper and zinc levels. The higher availability of the essential elements can be explained according to the fact that absorption and membrane transport of some metal ions were enhanced when they form complexes and chelates with organic ligands. Similarly, many data were reported on metal binding to proteins in the cells (60), and the higher availability of chelated elements may be linked to the shielding of the minerals positive charge during chelation.

Polyphenolic compounds had higher affinities with trace elements to form complexation ligand in vivo; this may explain the restoration of some trace elements in some organs after treatment with NIN, which may enhance the endogenous enzyme activities and minimize trace elements alterations induced by $\gamma$-radiation and /or iron dextran.

\section{CONCLUSION}

NIN can be effective in reducing the severity of biochemical disorders and oxidative damage induced by $\gamma$-radiation as well as ID toxicity induced in rat kidney. This proves the importance of NIN as antioxidant, metal chelating and free radical scavenger.

\section{ACKNOWLEDGMENT}

The authors are deeply appreciative to the staff members of $\gamma$-irradiation unit (NCRRT) for their generous support in carrying out the experimental irradiation.

Conflicts of interest: Declared none. 


\section{REFERENCES}

1. Abou Zeid SM, EL-Bialy BE, Nermeen B, EL- Borai NB, Abu Bakr HO, Elhadary AA (2018) Radioprotective effect of Date syrup on radiation- induced damage in Rats. Scient Reports, 8(1): 7423-7433.

2. Najafi SD, Musa AE, Keshavarz M, Shirazi AR, Hassanzadeh G, Hadian MR, Samandari H (2019) Biochemical and histopathological evaluation of the radioprotective effects of melatonin against $\gamma$ ray-induced skin damage. Curr Radiopharmaceuticals, 12: 1-9.

3. Abd El Rahman NA, Kamal El-Dein EM, Abd El-Hady AM, Saeed M, Soliman AM (2016) Radioprotective effects of adenosine in $\gamma$ irradiated rats. Pakistan J Zool, 48(6): 19711978.

4. Wish JB, Aronoff GR, Bacon BR, Brugnara C, Eckardt K, Ganz T, Macdougall IC, Núñez J, Perahia AJ, Wood JC (2018) Positive iron balance in chronic kidney disease: How much is too much and How to tell? Am J Nephrol, 47: 72-83.

5. Jagetia GC and Lalramthari (2018) Attrition of ironinduced biochemical injury in mice kidney by a citrus bioflavonoid, hesperidin. Biochem Physiol, 7(2): 240- 248.

6. Galaris D and Pantopoulos K (2008) Oxidative stress and iron homeostasis: mechanistic and health aspects. Crit Rev Clin Lab Sci, 45(1): 1-23.

7. Roberts WL, Smith PT, Martin WJ, Rainey PM (1999) Performance characteristics of three serum iron and total iron -binding capacity methods in acute iron overdose. Am J Clin Pathol, 112: 657-664.

8. Arosio P, Elia L, Poli M (2017) Ferritin, cellular iron storage and regulation. IUBMB Life, 69: 414-422.

9. Nishida Y (2009) Structural Characteristic of iron (III) chelates to induce tissue damage and renal carcinoma; chemical origin of the iron toxicity. TCI Mail, 141: 1- 5.

10. Asif M (2015) Chemistry and antioxidant activity of plants containing some phenolic compounds. Chemistry International, 1(1): 35-52.

11. Shine VJ, Anuja GI, Pradeep S, Suja SR (2018) Molecular interaction of naringin and its metabolite naringenin to human liver fibrosis proteins. Phcog Mag, 1(55): 102-109.

12. Lv X, Zhao S, Ning Z, Zeng H, Shu Y, Tao O, et al. (2015) Citrus fruits as a treasure trove of active natural metabolites that potentially provide benefits for human health. Chem Cent J, 9(68): 1-14.

13. Lim Y J, Kim JH, Pan JH, Kim JK, Park TS, Kim YJ, Lee JH, Kim JH (2018) Aringin protects pancreatic $\beta$-cells against oxidative stress-induced apoptosis by inhibiting both intrinsic and extrinsic pathways in insulin-deficient diabetic mice. Mol Nutr Food Res, 4: 1-10.

14. Shalini Ch, Pranesh K, Ashok S, Vinit R, Amit R, Amit K, Anand P, Sudipta S (2017) Protective effect of naringin against pylorus ligation-induced esophagitis in male Wistar rats. Ind J Pharma Sci, 79(2): 250-256.

15. Zhao Y, Li H, Gao Z, Xu H (2011) Effects of dietary baicilin supplementation on iron overload-induced mouse liver oxidative injury. Eur J Pharmacol, 2005; 509: 195-200.
16. Pari L and Amudha K (2011) Hepatoprotective role of naringin on nickel-induced toxicity in male Wistar rats. Eur J Pharmacol, 650(1): 364-70.

17. Yoshioka T, Kawada K, Shimada T, Mori M (1979) Lipid peroxidation in maternal and cord blood protective mechanism against activated-oxygen toxicity in the blood. $A m \mathrm{~J}$ Obstet Gynecol, 135(3): 372-376.

18. Vrablic AS, Albright CD, Craciunescu CN, Salganik RI, Zeisel SH (2001) Altered mitochondrial function and over generation of reactive oxygen species precede the induction of apoptosis by 1-0-octadecyl-2-methyl-rac-glycero-3phosphocholine in p53-defective hepatocytes. FASEB J, 15 (10): 1739- 1744.

19. Onosaka $S$ and Cherian MG (1982) The induced synthesis of metallothionein in various tissues of rats in response to metals. II: Influence of Zinc status and specific effect on pancreatic metallothionein. Toxicol, 23 (1): 11-20.

20. Beutler E, Duron O, Kelly MB (1963) Improved method for determination of blood glutathione reduced. J Lab Clin Med, 61: 882- 888.

21. Minami M and Yoshikawa HA(1979) Simplified Assay Method of Superoxide Dismutase Activity for Clinical Use. Clinica Chimica Acta, 92: 337-342.

22. IAEA (1980) Elemental analysis of biological materials. International Atomic Energy Agency. IAEA, Veinna Technical Reports Serie; 197: 379.

23. Milton JS, Corbert JJ, McTeer PM (1986) Introduction to statistics, $3^{\text {rd }}$ edn. D.C. Heath and Company, Toronto.

24. Kempner ES (2001) Effects of high-energy electrons and $y$ rays directly on protein molecules. J Pharm Sci, 90(10): 1637-1646.

25. Kheirallah DA and El-Samad LM (2016) Biochemical changes induced by $\gamma$ irradiation in the ground beetle blaps polycresta. J Advances Biology, 9(3): 1937- 1947.

26. Asare GA, Mossanda KS, Kew MC, Paterson AC, KahlerVenter CP, Siziba K (2006) Hepatocellular carcinoma caused by iron overload: A possible mechanism of direct hepatocarcinogenecity. Toxicol, 219: 41-52.

27. Benhar M, Engelberg D, Levitzki A (2002) ROS, stressactivated kinases and stress signaling in cancer. $E M B O$ Rep, 3: 420- 425.

28. Hamza RG, Mounir AM, El Shahat AN (2019) Studying the ameliorative effect of bee venom against damage and inflammation induced in $\mathrm{\gamma}$-irradiated rats. Arab J Nucl Sci Applic, 52(1): 178-184.

29. Alkhatib B, Al-Domi H, Shomaf M, Abu Irmaileh B (2017) Iron overload effect on serum levels of glucose, insulin and HOMA-IR was influenced by the type of fat in female Sprague-Dawley rats fed high-fat-diets. J Clin Nutr Diet, 3: 1-9.

30. Choi JS, Koh IU, Lee HJ, Kim WH, Song J (2013) Effects of excess dietary iron and fat on glucose and lipid metabolism. J Nutr Biochem, 24: 1634-1644.

31. Talebpour Amiri I, Hamzeh M,_Naeimi RA, Ghasemi A, Hosseinimehr SJ (2018) Radioprotective effect of atorvastatin against ionizing radiation-induced nephrotoxicity in mice. Int J Rad Biol, 94(2): 106- 113.

32. Amer N, Al Chami Z, Al Bitar L, Mondelli D, Dumontet $S$ 


\section{Ali et al. / Radioprotective effect of naringin against kidney injury}

(2013) Evaluation of atriplex halimus, medicago lupulina and portulaca oleracea for phytoremediation of $\mathrm{Ni}, \mathrm{Pb}$ and Zn. Int J Phytoremediat, 15(5): 498-512.

33. Rasool M, Malik A, Jabbar U, Begum I, Qazi MH, Asif M, et al. (2016) Effect of iron overload on renal functions and oxidative stress in beta thalassemia patients. Saudi Med J, 37(11): 1239-1242.

34. Ishizaka N, Saito, K, Noiri E, Sata M, Mori I, Ohno M, et al. (2004) Iron dextran causes renal iron deposition but not renal dysfunction in angiotensin II-treated and untreated rats. Neph Physiol, 98: 107-113.

35. Sponsel HT, Alfrey AC, Hammond WS, Durr JA, Ray C, Anderson RJ (1996) Effect of iron on renal tubular epithelial cells. Kidney Int, 50: 436- 444.

36. Prasad NR, Menon VP, Vasudev V, Pugalendi KV (2005) Radioprotective effect of sesamol on $\gamma$ - irradiation induced DNA damage, lipid peroxidation and antioxidants levels in cultured human lymphocytes. Toxicol, 209: 225-235.

37. Gudkov SV, Shtarkman IN, Smirnova VS, Chernikov AV, Bruskov VI (2006) Guanosine and inosine display antioxidant activity, protect DNA in vitro from oxidative damage induced by reactive oxygen species, and serve as radioprotectors in mice. Radiat Res, 165: 538-545.

38. Ping X, Junqing J, Junfeng J, Enjin J (2012) Radioprotective effects of troxerutin against $\psi$ irradiation in mice liver. Int $J$ Radiat Biol, 88(8): 607- 612

39. Valko M, Morris H, Cronin MT (2005) Metals, toxicity and oxidative stress. Curr Med Chem, 12: 1161- 1208.

40. Lu W, Zhao M, Rajbhandary S, Xie F, Chai X, Mu J, Meng J, Liu Y, Jiang $Y, X u$ X, Meng A (2013) Free iron catalyzes oxidative damage to hematopoietic cells/mesenchymal stem cells in vitro and suppresses hematopoiesis in iron overload patients. Eur J Haematol, 91(3): 249-261.

41. Hou YJ, Zhao YY, Xiong B, Cui XS, Kim NH, Xu YX, et al. (2013) Mycotoxin-containing diet causes oxidative stress in the mouse. PLoS One, 8: 60374.

42. Azadmanesh J and Borgstahl GEO (2018) A review of the catalytic mechanism of human manganese superoxide dismutase. Antioxidants (Basel), 7 (2): pii: E25-35.

43. Okada S (1970) Radiation induced death. In: "Radiation biochemistry" (Altman, K. I., Gerber, G. B. and Okada, S. Eds), Academic Press, New York. I: 247-285.

44. Pierrel F, Cobine PA, Winge DR (2007) Metal ion availability in mitochondria. Biometals, 20(3-4): 657- 82.

45. Heunks LM, Viña J, van Herwaarden $C L$, Folgering $H T$, Gimeno A, Dekhuijzen PN (1999) Xanthine oxidase is involved in exercise-induced oxidative stress in chronic obstructive pulmonary disease. Am J Physiol, 277: 16971704.

46. Alden CL and Frith CH (1991) Urinary system. In: Handbook of Toxicologic Pathology. Haschek WM, Rousseaux CG (Eds). Academic Press, San Diego 315-387.

47. Kotb MA, El-Khatib AM, Morsey AA, Ramadan MIA, ElBassiouni EA (1990) Changes in mineral elements tissues of mice following neutron irradiation. Isotop-enpaxis, 26 (7): 297-300

48. Gorbunov DV, Semenov DV, Shipitsin MV, Kit YY, Kanyshkova TG, Buneva VN, Nevinsky GA (2000) Phosphorylation of Minor Lipids of Human Milk Tightly Bound to Secretory Immunoglobulin A. Russ J Immunol, 5(3): 267 $-278$.

49. Garcia-Fernandez M, Castilla-Cortazar I, Diaz-Sanchez M, Navarro I, Puche JE, Castilla A, et al. (2005) Antioxidant effects of insulin-like growth factor-1 (GF-1) in rats with advances liver cirrhosis. BMC Gastroenterol, 5(7): 1-8.

50. Rosser BJ and Gores GJ (1995) Liver cell necrosis: cellular mechanisms and clinical amplications. Gastroenterology, 108(1): 252-275

51. Klevay LM (2016) IHD from copper deficiency: a unified theory. Nutr Res Rev, 29(2): 172-179.

52. Ha JH, Doguer C, Wang X, Flores SR, Collins F (2016) HighIron Consumption Impairs Growth and Causes copperdeficiency anemia in weanling sprague-dawley rats. PLOS One, 11(8): 1-19.

53. Al Fartosy AJM, Shanan S K, Awad NA (2017) Biochemical study of the effects of some heavy metals on oxidant / antioxidant status in gasoline station workers /Basra-Iraq. Int J Sci and Res, 7(2): 83-94.

54. Salem M, Kholoussi S, Kholoussi N, Fawzy R (2011) Malondialdehyde and trace element levels in patients with type 2 diabetes mellitus. Archeves of Hellinic Medicine, $\mathbf{2 8}$ (1): 83-88.

55. Noaman E and El-Kabany H (2002) Effect of novel copper compound (CU-BISDO) and $v$ irradiation on copper and zinc concentration, ceruloplasmin and superoxide dismutase activity in mice loaded with Ehlirich tumor. Egy $J$ Biomed Sci, 9: 209-223.

56. Jeon SM, Park YB, Choi MS (2004) Antihypercholesterolemic property of naringin alters plasma and tissue lipids, cholesterol-regulating enzymes, fecal sterol and tissue morphology in rabbits. Clinical Nutrition, 23: 1025-1034.

57. Adil M, Visnagri A, Kumar VS, Kandhare AD, Ghosh $P$ (2014) Protective effect of naringin on sodium arsenite induced testicular toxicity via modulation of biochermical perturbations in experimental rats. Pharmacologia, 5: 222 -234 .

58. Kandhare AD, Raygude KS, Ghosh P, Ghule AE, Bodhankar SL (2012) Neuroprotective effect of naringin by modulation of endogenous biomarkers in streptozotocin induced painful diabetic neuropathy. Fitoterapia, 83(4): 650- 659.

59. Jagetia GC and Lalnuntluangi $V$ (2016) The citrus flavanone naringin enhances antioxidant status in the albino rat liver treated with doxorubicin. Biochem Mol Biol J, 2 (2): 1-9.

60. Murariu M, Dragan ES, Drochioiu G (2010) Electrospray ionization mass spectrometric approach of conformationally-induced metal binding to oligopeptides. Eur J of Mass Spect, 16(4): 511-521. 